\title{
Comparison between Airlift Photobioreactor and Bubble Column for Skeletonema costatum cultivation
}

\author{
Saranya Monkonsit ${ }^{1}$, Sorawit Powtongsook ${ }^{2,3}$, and Prasert Pavasant ${ }^{1, *}$ \\ 1Department of Chemical Engineering, Faculty of Engineering, Chulalongkorn University, Bangkok \\ 10330, Thailand \\ 2Center of Excellence for Marine Biotechnology, Department of Marine Science, Faculty of Science, \\ Chulalongkorn University, Bangkok 10330, Thailand \\ 3National Center of Genetic Engineering and Biotechnology, National Science and Technology \\ Development Agency, Pathumthani 12120, Thailand \\ E-mail: prasert.p@ chula.ac.th*
}

\begin{abstract}
The cultivation of diatom Skeletonema costatum was achieved in airlift photobioreactor and the system performance was compared to that of bubble column. The standard F/2 medium (Guillard's medium) for typical diatom cultivation could only yield the best growth character when the silicon concentration increased 4 times the normal value. In terms of cell growth, the airlift photobioreactor provided better performance than the bubble column where the maximum cell concentration, specific growth rate, and productivity in the airlift were $4.6 \times 10^{6}$ cells $\mathrm{mL}^{-1}, 0.07 \mathrm{~h}^{-1}$, and $6.4 \mathrm{x}$ $10^{4}$ cells s $\mathrm{s}^{-1}$ compared with $1.8 \times 10^{6}$ cells $\mathrm{mL}^{-1}, 0.04 \mathrm{~h}^{-1}$, and $2.2 \times 10^{4}$ cells s${ }^{-1}$ in the bubble column of the same size $(3 \mathrm{~L})$ and operated at the same aeration rate (superficial velocity $\left.=1.5 \mathrm{~cm} \mathrm{~s}^{-1}\right)$ and light intensity $\left(34 \mu \mathrm{mol}\right.$ photons $\left.\mathrm{m}^{-2} \mathrm{~s}^{-1}\right)$. This was because the airlift photobioreactor allowed circulatory flow in the system which helps prevent cell precipitation and enhance light utilization efficiency. The optimal operating conditions in the airlift system which was found most optimal to cell growth were: the ratio between downcomer and riser cross sectional area $\left(A_{d}: A_{r}\right)$ of 3.27 , superficial gas velocity $1.5 \mathrm{~cm} \mathrm{~s}^{-1}$ and the light intensity $34 \mu \mathrm{mol}$ photons $\mathrm{m}^{-2} \mathrm{~s}^{-1}$. Preliminary economical assessment on the cultivation of $S$. costatum in airlift system compared with that in bubble column was carried out, whereas the analysis for nutritional values of the obtained biomass indicated relatively high protein content.
\end{abstract}

Keywords: Diatom, microalgae, cultivation, bioreactor, aquaculture.

ENGINEERING JOURNAL Volume 15 Issue 4

Received 15 June 2011

Accepted 11 August 2011

Published 1 October 2011

Online at http://www.ej.eng.chula.ac.th/eng/

DOI:10.4186/ej.2011.15.4.53 


\section{Introduction}

Food for shrimp larvae in the first protozoea stage (zoea stage) in Thailand is generally diatoms [1] as they contain essential nutrients, and also have proper size allowing a faster and healthier growth of the larvae [2]. The use of natural feed like diatom also induces less water pollution compared to artificial feed. Small diatom such as Chaetoceros gracilis and Skeletonema costatum are typically employed for this purpose where Chaetoceros gracilis is usually used in the eastern part of Thailand and Skeletonema costatum is usually in the south, both being equally popular, the choice of which depends on experience of the farmers.

The cultivation of both Chaetoceros gracilis and Skeletonema costatum in Thailand is generally performed in 3 steps: Step 1: stock culture of the diatom is cultivated as dense cell culture in a $1 \mathrm{~L}$ Erlenmeyer flask for 8-12 days; Step 2: the culture is then inoculated in a bigger container such as plastic tanks, this takes around 4-5 days; Step 3: the cells from Step 2 are being scaled up in a larger scale tank 2-10 cubic meters in volume, typically cement tanks, this will be another 2-3 days before it is ready to be used. However, the drawback of this method is that the cultivation in the last steps is done in an open space which is more susceptible to contamination causing subsequent destructive diseases in shrimp culture ponds. The design of closed system bioreactors is therefore treated as a solution to these problems.

Airlift bioreactor (ALBR) is one of the potential alternatives for the cell cultivation [3]. Airlift bioreactors achieve mixing and mass transfer by injecting air into the riser compartment which then allows the fluid circulation through the downcomer compartment. The mixing in the airlift bioreactor could be obtained without causing too much shear force in the liquid phase which could inhibit the growth of the diatom. Our recent work has proven that, by giving it a good design and operating conditions, the use of airlift system as a photobioreactor could drastically improve the quality of the cultivation of Chaetoceros calcitrans $[4,5]$.

This work aimed to extend the applicability of the airlift system onto the cultivation of Skeletonema costatum. The main target was to determine the optimal design configurations and operating conditions for the growth of Skeletonema costatum.

\section{Experimental}

Skeletonema costatum BIMS-PP0115 was obtained from Bangsaen Institute of Marine Science, Burapha University, Thailand. The standard F/2 medium [6] was employed as the standard medium where the composition of this standard medium is given in Table 1.

The experiments were investigated in clear acrylic plastic bubble column (Fig. 1(a)) and airlift photobioreactor (Fig. 1(b)) with dimensions as shown in Table 2. The airlift was equipped with a draft tube installed centrally in the column. Air from an air compressor was metered through a flowmeter, sterilized with a $0.45 \mu \mathrm{m}$ Gelman filter and passed into the culture at the bottom of both reactors. Light was supplied through fluorescent lamp (18 watts) at the side along the length of the column (2 lamps for each column), and light intensity was measured by "Digicon LX-50 lux meter" around the column, and was then converted into $\mu$ mol photons $\mathrm{m}^{-2} \mathrm{~s}^{-1}$ with the conversion factor of 74 . The temperature was controlled at $25-30^{\circ} \mathrm{C}$ using an air conditioning unit.

Note that the analyses for silicon, nitrogen and phosphorus follow the methods as proposed by Fanning and Pilson [7], Armstrong [8], and Fontaine [9], respectively. 
Table 1. Chemical composition of standard F/2 (Guillard's) stock solution*.

Solution A: Nitrate and Phosphate stock solution (1 L)

\begin{tabular}{cc}
\hline Nutrient & Amount \\
\hline $\mathrm{NaNO}_{3}$ & $84.15 \mathrm{~g}$ \\
$\mathrm{Na}_{2} \mathrm{HPO}_{4} \cdot \mathrm{H}_{2} \mathrm{O}$ & $6.0 \mathrm{~g}$ \\
$\mathrm{FeCl}_{3} \cdot 6 \mathrm{H}_{2} \mathrm{O}$ & $2.90 \mathrm{~g}$ \\
$\mathrm{Na}_{2} \mathrm{EDTA}_{2} \cdot \mathrm{H}_{2} \mathrm{O}$ & $10.0 \mathrm{~g}$ \\
\hline
\end{tabular}

Solution B: Silicate stock solution (1 L)

\begin{tabular}{cc}
\hline Nutrient & Amount \\
\hline $\mathrm{Na}_{2} \mathrm{SiO}_{3} \cdot 9 \mathrm{H}_{2} \mathrm{O}$ & $33.0 \mathrm{~g}$ \\
\hline & \\
\hline & \\
\hline & \\
\hline Nolution C: Trace metal stock solution $(\mathbf{~ L})$ & Amount \\
\hline $\mathrm{CuSO}_{4} \cdot 5 \mathrm{H}_{2} \mathrm{O}$ & $1.96 \mathrm{~g}$ \\
$\mathrm{ZnSO}_{4} \cdot 7 \mathrm{H}_{2} \mathrm{O}$ & $4.40 \mathrm{~g}$ \\
$\mathrm{Na}_{2} \mathrm{MoO}_{4} \cdot 2 \mathrm{H}_{2} \mathrm{O}$ & $1.26 \mathrm{~g}$ \\
$\mathrm{MnCl}_{2} \cdot 4 \mathrm{H}_{2} \mathrm{O}$ & $36.0 \mathrm{~g}$ \\
$\mathrm{CoCl}_{2} \cdot 6 \mathrm{H}_{2} \mathrm{O}$ & $2.0 \mathrm{~g}$ \\
\hline
\end{tabular}

Solution D: Vitamin stock solution (1 L)

\begin{tabular}{cc}
\hline Nutrients & Amount \\
\hline Vitamin B1 & $0.4 \mathrm{~g}$ \\
Vitamin B12 & $0.002 \mathrm{mg}$ \\
Biotin & $0.10 \mathrm{mg}$ \\
\hline
\end{tabular}

*Remark: To prepare the culture medium for Skeletonema costatum, simply add $1 \mathrm{~mL}$ of solutions A, B, $\mathrm{C}$ and $\mathrm{D}$ in $1 \mathrm{~L}$ of fresh sea water.

Table 2. Main dimension of the bioreactor.

\begin{tabular}{lcc}
\hline & Bubble column & Airlift photobioreactor \\
\hline Column inner diameter (D), cm & 9.4 & 9.4 \\
Column height (H), cm & 60 & 60 \\
Draft tube height (h), cm & - & 40 \\
Working volume (V), L & 3 & 3 \\
\hline
\end{tabular}




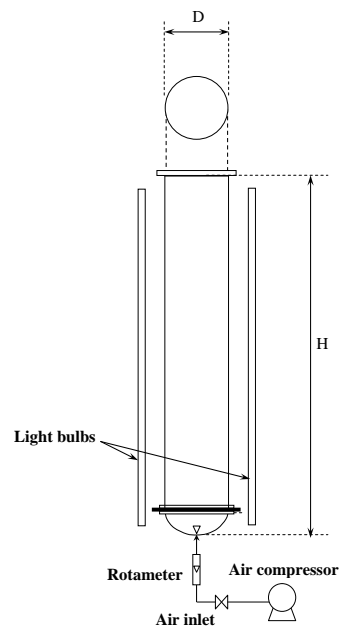

(a) Bubble column

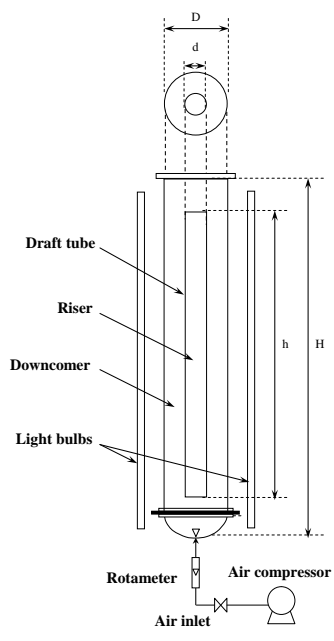

(b) Airlift photobioreacter

Fig. 1. Experimental setups.

\section{Results and Discussion}

\subsection{Limiting nutrients for growth of $S$. costatum with standard $F / 2$ medium}

Batch experiments were carried out to determine growth limiting nutrients using $2 \mathrm{~L}$ glass bottle (superficial gas velocity of $1.5 \mathrm{~cm} \mathrm{~s}^{-1}$ and light intensity of $33.78 \mu \mathrm{mol}$ photons $\mathrm{m}^{-2} \mathrm{~s}^{-1}$ ). The cultures were started with an initial cell concentration of $0.4 \times 10^{6}$ cells $\mathrm{mL}^{-1}$ and time profiles of the nutrient concentrations were illustrated in Fig. 2. During the initial lag phase where very slow growth was observed, nutrients concentration remained at the concentration level in F/2 medium. Once cells entered the exponential phase, all nutrients were being consumed quite quickly. Phosphate concentration seemed to be consumed drastically and the level of phosphate in the medium went down to almost zero. Two possibilities existed here. First, it could be that cells accumulated energy during the growth in the form of adenosine triphosphate (ATP) which required a significant uptake of phosphorus. On the other hand, it was also probable that precipitation of phosphate occurred at the alkalinity level employed in this work. Silicon was also being consumed quite significantly and the level of silicon also considerably reduced. This is what expected for the cultivation of diatoms as $\mathrm{Si}$ is an important constituent in cell wall, and a significant amount is needed for cell division. Nitrogen is one important element for protein synthesis by photosynthesis and is conventionally supplied to the culture in nitrate form. Nitrate, despite being consumed in a much higher quantity when compared with $\mathrm{Si}$ and $\mathrm{P}$, was still left in a reasonably high content. 

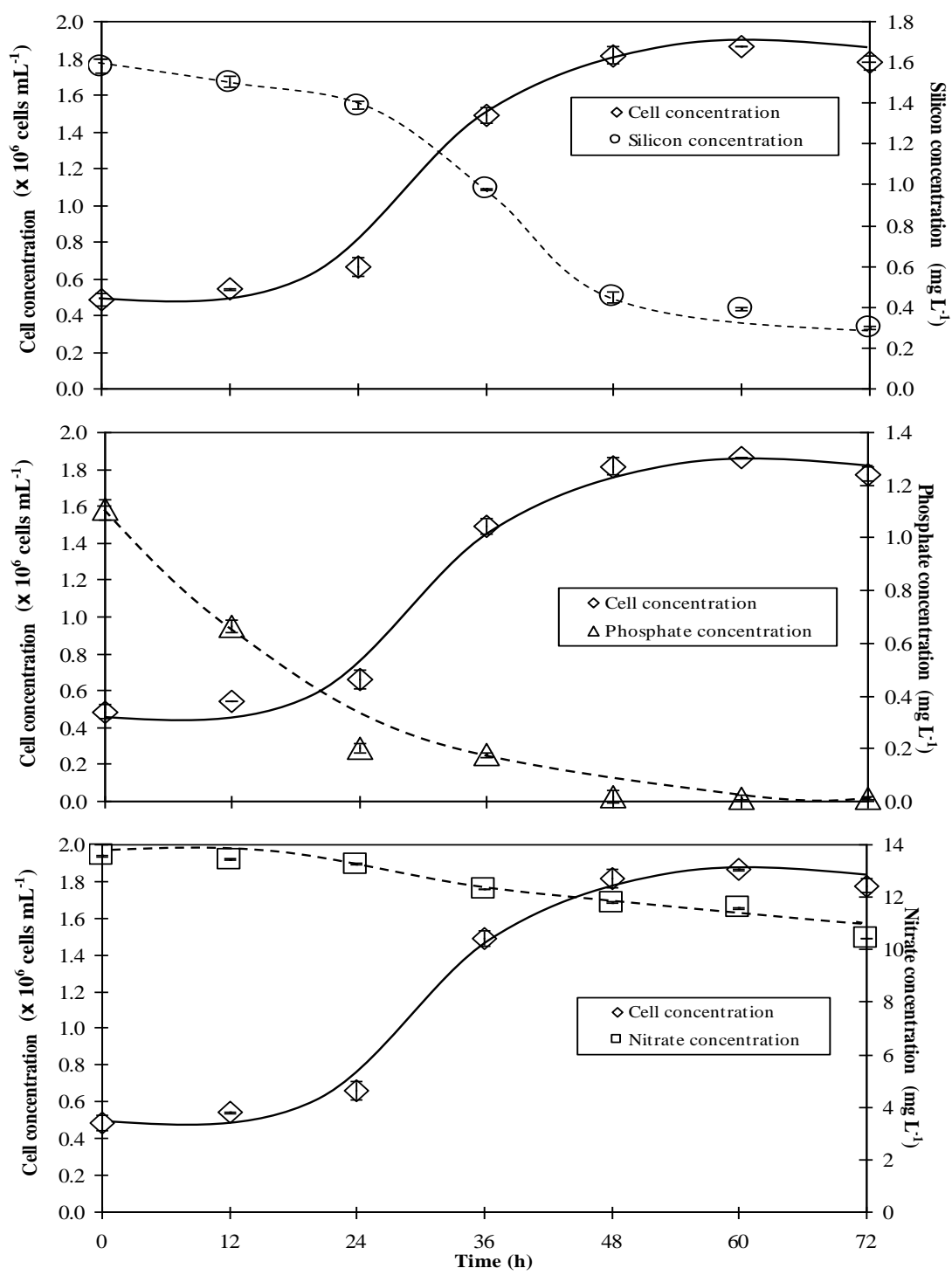

Fig. 2. Cell and nutrients concentration during batch cultivation of S. Costatum.

\subsection{Effects of silicon and phosphate concentrations on cell growth}

Results from the preliminary assessment in the previous section led to the conclusion that phosphate and silicon could be rate limiting factor for the growth of $S$. costatum. Further investigation was then carried out to see the effects of silicon and phosphate concentrations on the growth of the diatom and the results are illustrated in Fig. 3 and 4.

Fig. 3 illustrates clearly that $S$. costatum grew better when extra quantity of silicon was added into the standard F/2 medium. Increasing silicon from 1 to 4 fold of the standard concentration clearly induced higher growth rate and productivity. The highest maximum cell concentration of almost $4.6 \times 10^{6}$ cells $\mathrm{mL}^{-1}$ occurred at 4 fold silicon content. However, an inhibition effect seemed to be observed when the silicon concentration increased more than 4 folds. 


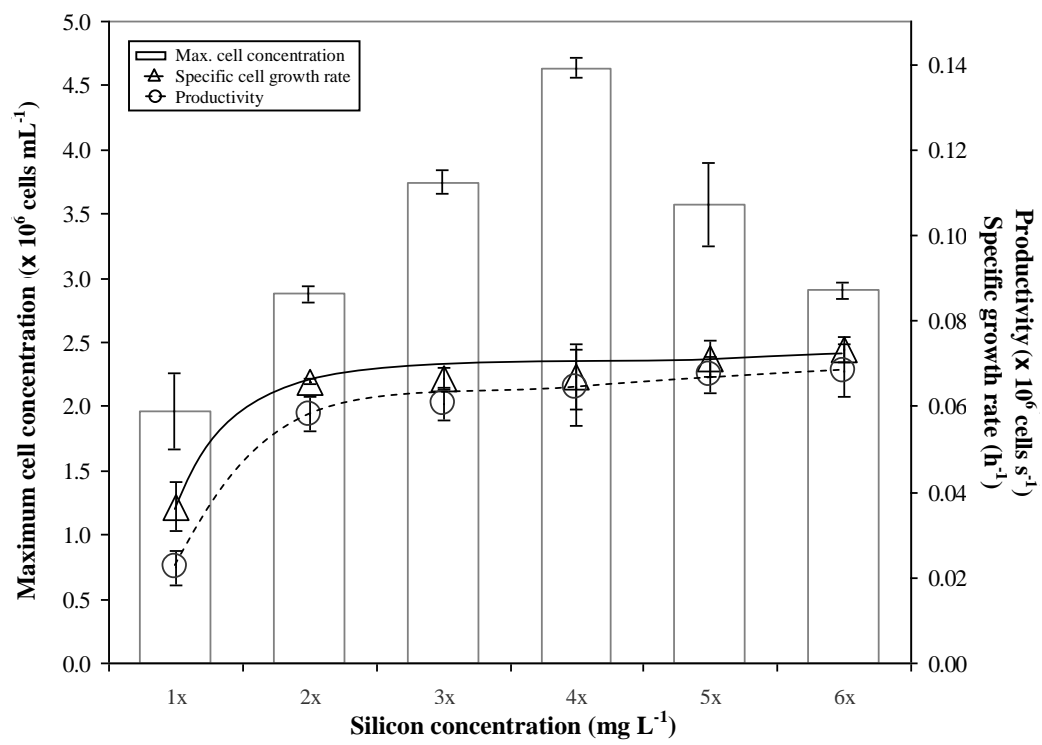

Fig. 3. Effect of silicate concentration (measured as silicon) from 1 to 6 folds of standard F/2 medium on cell growth.

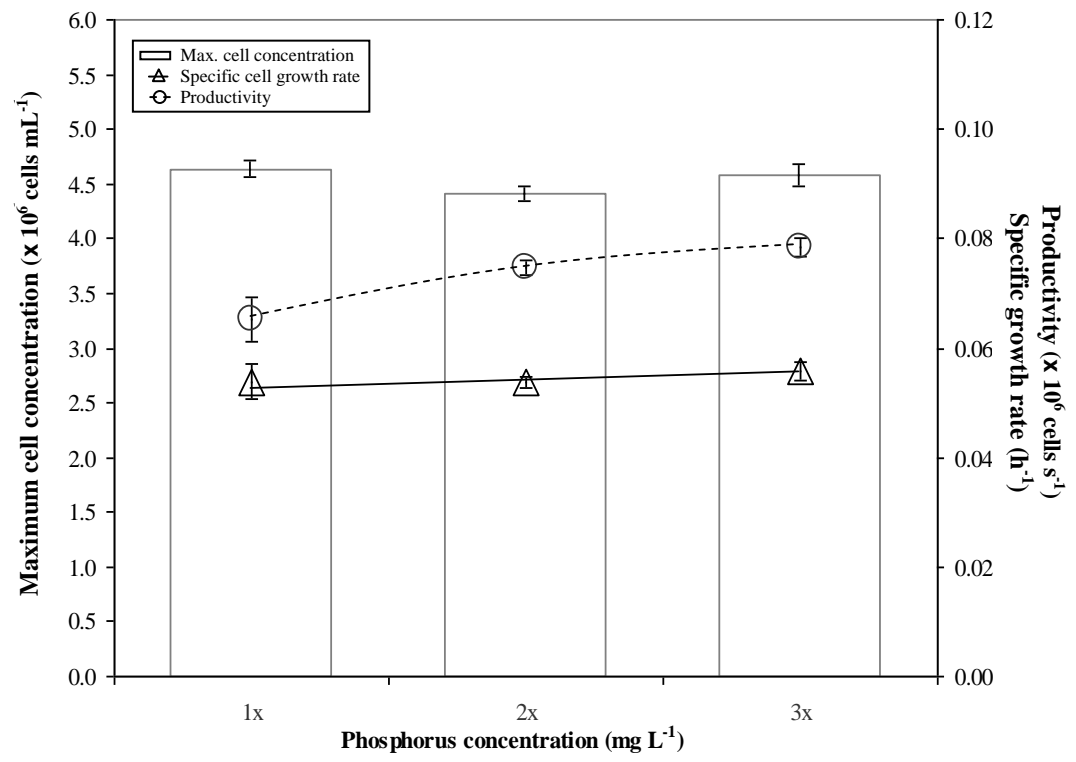

Fig. 4. Effect of phosphate concentration (measured as phosphorus) from 1 to 3 folds of standard F/2 medium on cell growth.

Phosphorus plays an important role in almost all cell metabolic activities, and it is an important component of cell membrane. Phosphate is also an important component of the energy storage melucules, adenosine triphosphate (ATP), Nicotinamide adenine dinucleotide phosphate (NADPH), etc. Insufficient supply of phosphorus can, hence, reduce the cell growth [10]. For this work, the effects of phosphorus concentration on the growth of $S$. costatum are demonstrated in Fig. 4. Note that this experiments were performed with silicon content of 4-fold the standard F/2 medium. This analysis showed that the addition of phosphorus concentration from $1 \mathrm{x}$ to $3 \mathrm{x}$ did not have significant impacts on the maximum cell concentration and productivity, and the original concentration was concluded to be the optimal level.

The cellular yield based on the nutrient component or $\mathrm{Y}_{\mathrm{Nu} / \mathrm{X}}$ can be evaluated using the following equation:

$$
Y_{N u / X}=\frac{\Delta N u / \Delta t}{\Delta X / \Delta t}
$$


when $\quad \Delta N u / \Delta t=$ specific nutrient uptake $\left(\mathrm{mg} \mathrm{L}^{-1} \mathrm{~s}^{-1}\right)$

$\Delta X / \Delta t=$ cell production $\left(\right.$ cells $\left.\mathrm{mL}^{-1} \mathrm{~s}^{-1}\right)$.

In this work, the cellular yield for silicon, phosphorus and nitrogen can be summarized as follows:

$\begin{array}{ll}\text { silicon content: } & \mathrm{Y}_{\mathrm{Si} / \mathrm{X}}=0.4 \times 10^{-3} \mathrm{pg} \mathrm{cell}^{-1} \\ \text { phosphorus content: } & \mathrm{Y}_{\mathrm{P} / \mathrm{X}}=2.9 \times 10^{-3} \mathrm{pg} \mathrm{cell}^{-1} \\ \text { nitrogen content: } & \mathrm{Y}_{\mathrm{N} / \mathrm{X}}=5.5 \times 10^{-3} \mathrm{pg} \mathrm{cell}^{-1}\end{array}$

The ratio of the three major cellular chemical compositions, N:Si:P assimilated into the cell calculated from the ratio between these yields became 1.9:0.1:1. Literature revealed that the ratio of N:Si:P of $S$. costatum cultivated in chemostats under non-limiting nutrient [11] is 10:5.4:1 which means that the ratios between $\mathrm{N}$ and $\mathrm{Si}$ to $\mathrm{P}$ were much higher in the literature than those found in this work. This implied that, although $\mathrm{P}$ was totally consumed, it was already present in relatively high content when compared with other nutrients such as $\mathrm{Si}$ and $\mathrm{N}$. On the other hand, Si seemed to be inadequately provided in the standard F/2 medium (almost 50 times lower than the reported Si:P ratio of 5.4:1). Nitrogen was also not being supplied sufficiently as it was not the rate limiting factor for this case. This supports the finding that an increase in $\mathrm{Si}$ augmented the growth of the diatom.

Having discussed so, however, it was also possible that phosphorus was precipitated in the medium which is likely to take place particularly at neutral or high alkalinity conditions. In this case, it might be recommended that an intermittent or a continuous feed of phosphorus might be a more effective way of supplying phosphorus for the algal culture.

\subsection{Growth of S. costatum under different light intensities}

These experiments were conducted in the $3 \mathrm{~L}$ airlift photobioreactor with downcomer to riser cross sectional ratio $\left(\mathrm{A}_{\mathrm{d}} / \mathrm{A}_{\mathrm{r}}\right)$ of 3.27 , and $3 \mathrm{~L}$ bubble column operating at superficial velocity of $1.5 \mathrm{~cm} \mathrm{~s}^{-1}$ and at different levels of light intensities. Fig. 5 demonstrates quite clearly that the modified F/2 medium (with $4 \mathrm{x}$ silicon) outperformed the standard F/2 medium at all light intensities. The highest cell concentration, specific growth rate and productivity obtained from the standard F/2 medium at the light intensity around $34 \mu \mathrm{mol}$ photons $\mathrm{m}^{-2} \mathrm{~s}^{-1}$ were about $1.8 \times 10^{6}$ cells mL $\mathrm{m}^{-1}, 0.04 \mathrm{~h}^{-1}$ and $2.2 \times 10^{4}$ cells s${ }^{-1}$, respectively, which were less than those obtained from the culture with the modified F/2 medium at 4.6 x $10^{6}$ cells $\mathrm{mL}^{-1}, 0.07 \mathrm{~h}^{-1}$ and $6.4 \times 10^{4}$ cells s ${ }^{-1}$, respectively.

Figure 6 illustrates the effects of light intensity on the performance of airlift photobioreactor compared with that of bubble column. Similar correlation between light intensity and growth in both types of reactors was observed. The best results were obtained from the airlift system at the light intensity of $34 \mu \mathrm{mol}$ photons $\mathrm{m}^{-2} \mathrm{~s}^{-1}$. At low range of light intensity $\left(<34 \mu \mathrm{mol}\right.$ photons $\left.\mathrm{m}^{-2} \mathrm{~s}^{-1}\right)$, increasing the light intensity (from 20 to $34 \mu \mathrm{mol}$ photons $\mathrm{m}^{-2} \mathrm{~s}^{-1}$ ) helped induce photosynthesis and therefore an increase in maximum cell concentration, specific growth rate and productivity were observed. However, increasing light intensity above $34 \mu \mathrm{mol}$ photons $\mathrm{m}^{-2} \mathrm{~s}^{-1}$ was found to have negative impacts on the growth which could be due to the over-saturation of light that caused photoinhibition. The performance of bubble column was, unexpectedly, better than the airlift at high light intensity. This could be due to the effect of circulatory flow in the airlift which allowed all the cells to be exposed to high light intensity zone, and therefore the effect of high light intensity was distributed evenly throughout the culture. 


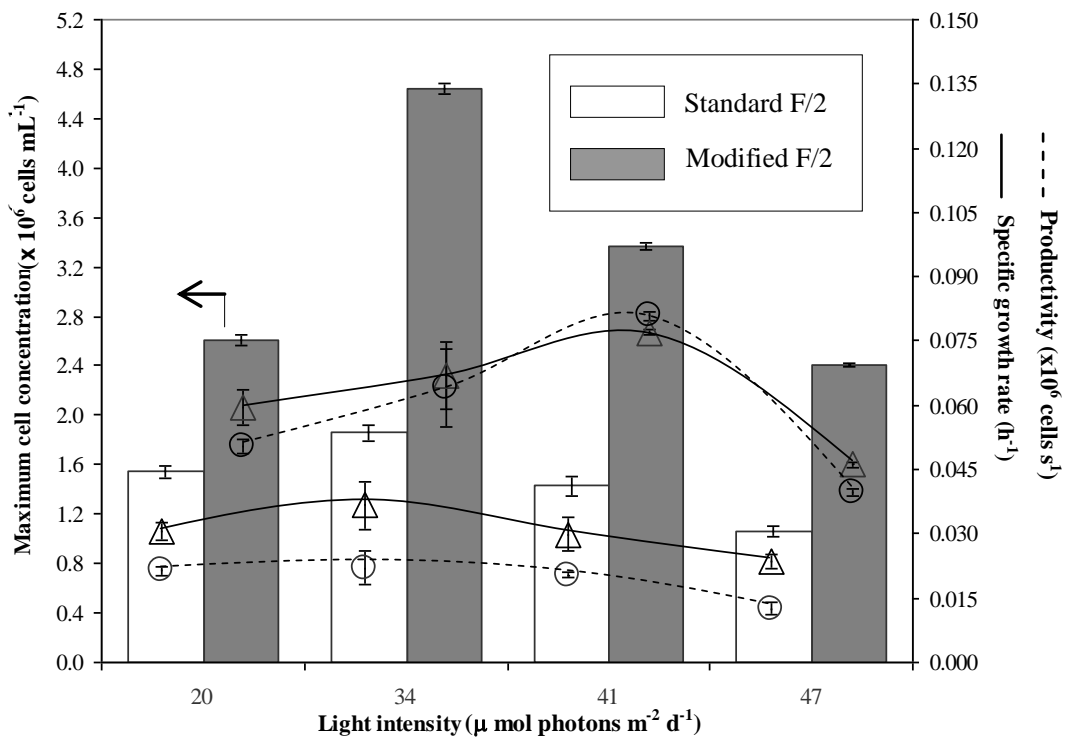

Fig. 5. Effect of light intensities on cell growth in airlift photobioreactor with standard $F / 2$ and modified F/2 mediums.

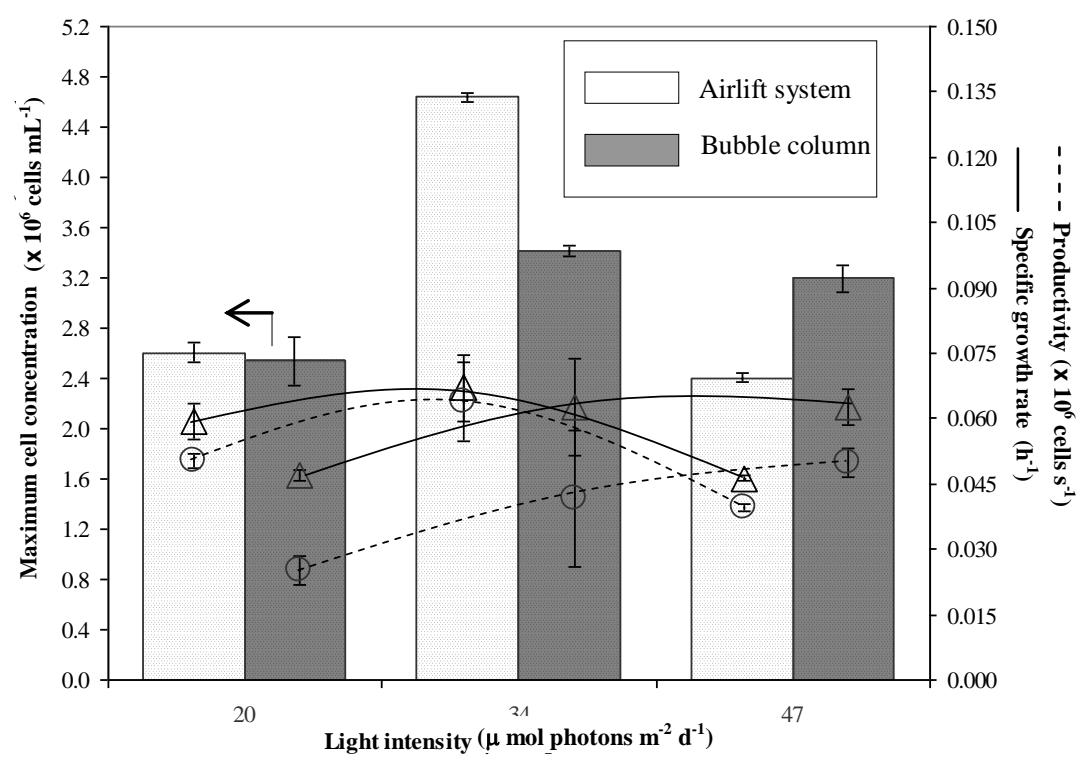

Fig. 6. Effect of light intensities on cell growth in airlift photobioreactor and bubble column operated with modified $\mathrm{F} / 2$ medium.

\subsection{Effect of aeration rate}

These experiments were conducted in the $3 \mathrm{~L}$ airlift photobioreactor with $\mathrm{A}_{\mathrm{d}} / \mathrm{A}_{\mathrm{r}}=3.27$ and $3 \mathrm{~L}$ bubble column operating at the light intensity of $34 \mu \mathrm{mol}$ photons $\mathrm{m}^{-2} \mathrm{~s}^{-1}$. In the airlift system, an increase in the aeration rate (measured in terms of superficial velocity, $\mathrm{u}_{\mathrm{sg}}$ ) from 1 to $1.5 \mathrm{~cm} \mathrm{~s}^{-1}$ led to a higher cell concentration, specific growth rate and productivity. However, increasing aeration rate above $1.5 \mathrm{~cm} \mathrm{~s}^{-1}$ was found to have negative impacts on the growth. This effect is illustrated in Fig. 7 which reveals that the airlift system still provided a better performance, but only at $\mathrm{u}_{\mathrm{sg}}$ of $1.5 \mathrm{~cm} \mathrm{~s}^{-1}$. At other $\mathrm{u}_{\mathrm{sg}}$, no significant differences between the two types of reactors were observed.

An increase in the aeration rate from 1 to $1.5 \mathrm{~cm} \mathrm{~s}^{-1}$ induced liquid circulation rate and mass transfer between gas and liquid phase in the system [12] which facilitated the removal of metabolic gases such as oxygen, preventing the accumulation of such gases, avoiding potential adverse effects on the growth rate [13]. The mixing of liquid caused a more homogeneity between the medium and cell which resulted 
in a more sufficient utilization of nutrients. This lead to a better growth performance as described earlier. On the other hand, a much too high aeration rate $\left(\mathrm{u}_{\mathrm{sg}}>1.5 \mathrm{~cm} \mathrm{~s}^{-1}\right)$ led to a system with more gas bubbles along the downcomer. These gas bubbles were somewhat undesirable as they could prevent the passage of light to the center of the bioreactor as the light penetration ability was obstructed and dissipated by the swarm of bubbles. Also the mass transfer rate between phases decreased as a result of decreasing specific mass transfer area (of large bubbles).

\subsection{Growth in airlift with different ratios between downcomer and riser cross section area}

This section investigates the effect of design configuration of the airlift photobioreactor system, i.e. the ratio between downcomer and riser cross sectional area $\left(\mathrm{A}_{\mathrm{d}} / \mathrm{A}_{\mathrm{r}}\right)$ on the growth of $S$. costatum. Experiment in this section was performed with the light intensity of $34 \mu \mathrm{mol}$ photons $\mathrm{m}^{-2} \mathrm{~s}^{-1}$. This parameter could be simply altered by changing the draft tube size. The four sizes of commercially available clear column were employed, i.e. at $3,5,6$ and $7 \mathrm{~cm}$, which gave $A_{d} / A_{r}$ of approximately $14.87,3.27,1.87$ and 0.98 , respectively. Fig. 8 illustrates quite clearly that the optimal growth behavior occurred at $A_{d} / A_{r}$ of 3.27. The specific growth rate might seem to be relatively high at larger $A_{d} / A_{r}$, but this only provided low cell density which also resulted in a low productivity. It was observed again here that the aeration rate of $\mathrm{u}_{\mathrm{sg}}=1.5 \mathrm{~cm} \mathrm{~s}^{-1}$ (results shown in Fig. 8) provided the best performance with the maximum cell concentration, specific growth rate and productivity of $4.6 \times 10^{6}$ cells mL $\mathrm{mL}^{-1}, 0.07 \mathrm{~h}^{-1}$ and $6.4 \times 10^{4}$ cells s$^{-1}$, respectively (results at other $\mathrm{u}_{\mathrm{sg}}$ are not shown here).

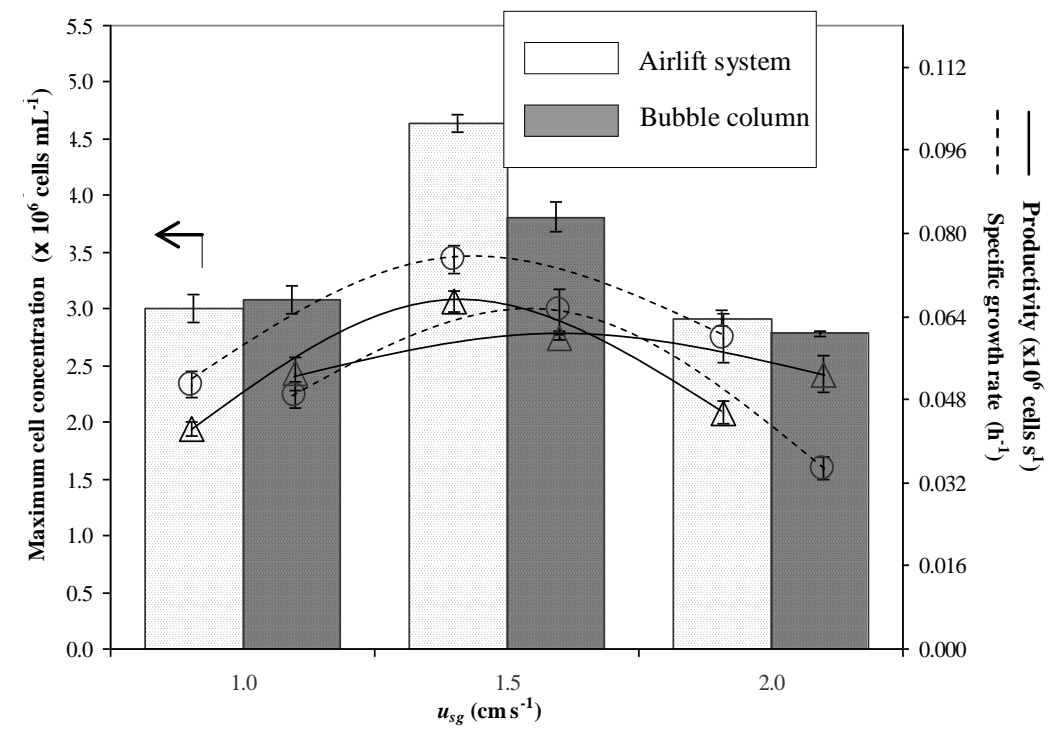

Fig. 7. Effect of aeration rate on cell growth in airlift photobioreactor and bubble column operated with modified F/2 mediums. 


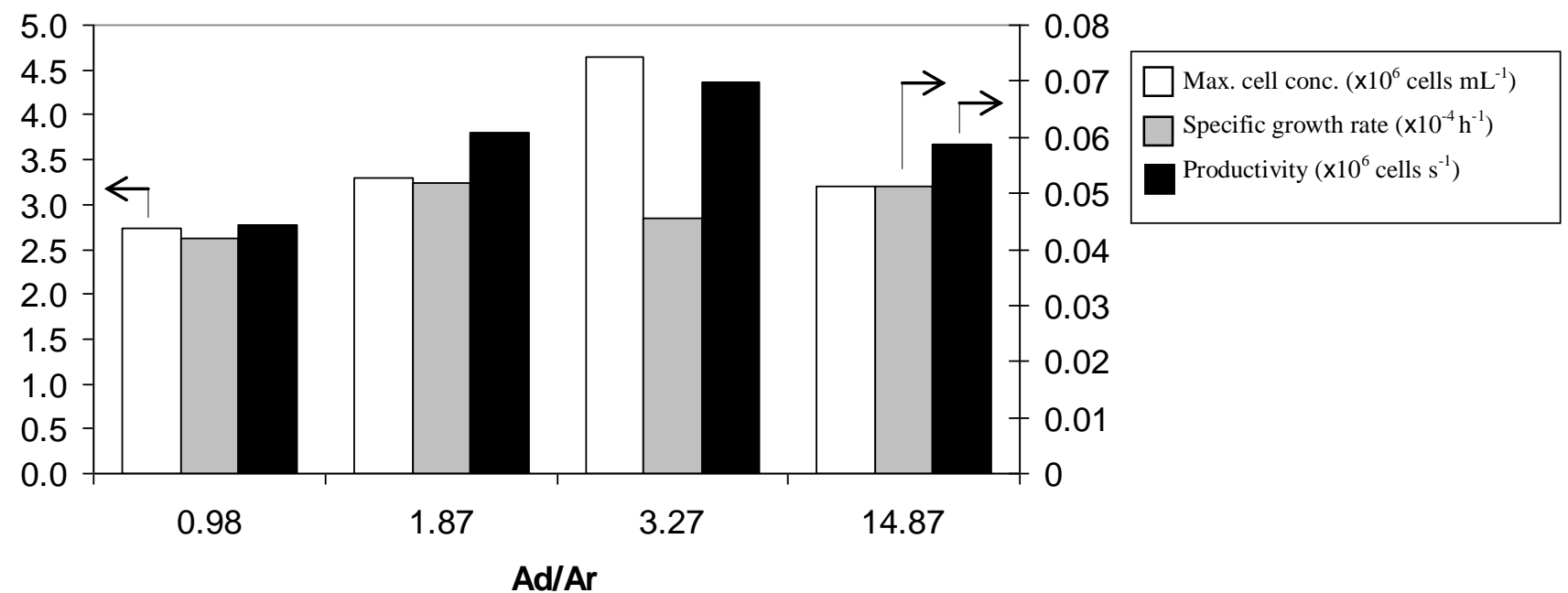

Fig. 8. Growth performance in airlift systems at various $A_{d} / A_{r}$ operated with modified $F / 2$ medium.

\subsection{Preliminary economic evaluation}

Preliminary economic consideration for the production of $1 \mathrm{~kg}$ of $S$. costatum was based on the cultivation in the airlift photobioreactor and bubble column operated in batch mode, and the results are presented in Table 3. The differences in the performance of the bubble column and airlift required that the total volume of sea water for the cultivation in airlift photobioreactor $(1,450 \mathrm{~L})$ was less than that for bubble column $(2,223 \mathrm{~L})$. Besides, some other advantages of airlift photobioreactor, such as the reducing number of time cycle for the cultivation of $S$. costatum allowed the airlift to be operated more effectively, and this was reflected in the analysis as the airlift seemed to be more attractive than the bubble column The specific operating cost for the cultivation in the airlift was approx. US\$ $0.09 \mathrm{~g}^{-1}$ (3.41 $\left.\mathrm{THB} \mathrm{g}^{-1}\right)$, which was $27 \%$ lower when compared with the cultivation in the bubble column $(0.13$ US $\$ \mathrm{~g}^{-1}$ or $4.66 \mathrm{THB} \mathrm{g}^{-1}$ ) Note that the investment cost was not included in this preliminary evaluation and the assessment was totally based on the laboratory scale production as employed in this work, the economical performance of the actual scale production could be significantly different from the resulted reported here.

Table 3. Economical analysis of the cultivation of $1 \mathrm{~kg}$ (dry weight) of S. costatum.

\begin{tabular}{|c|c|c|c|}
\hline \multirow{2}{*}{ Variable } & & \multicolumn{2}{|c|}{ Value } \\
\hline & & ALPBR & $\mathbf{B C}$ \\
\hline Effective volume (L) & {$[\mathrm{A}]$} & 3 & 3 \\
\hline Cycle time (h) & {$[\mathrm{B}]$} & 45 & 36 \\
\hline Maximum cell concentration (cells $\mathrm{mL}^{-1}$ ) & {$[\mathrm{C}]$} & $4.6 \times 10^{6}$ & $2.9 \times 10^{6}$ \\
\hline Cell mass concentration $\left(\mathrm{kg} \mathrm{L}^{-1}\right)$ & {$[\mathrm{D}]$} & $0.69 \times 10^{-3}$ & $0.45 \times 10^{-3}$ \\
\hline $\begin{array}{l}\text { Total volume of sea water used (L) } \\
\text { (based on } 1 \mathrm{~kg} \text { ) }\end{array}$ & {$[\mathrm{E}=1 \div \mathrm{D}]$} & 1450 & 2223 \\
\hline Number of reactor (reactor) & {$[\mathrm{F}=\mathrm{E} \div \mathrm{A}]$} & 484 & 741 \\
\hline Cost of water, $0.06 \mathrm{THB} \mathrm{L}^{-1}$ (THB) & {$[\mathrm{G}=0.06 \times \mathrm{E}]$} & 87 & 134 \\
\hline Cost of nutrient, 1 THB L ${ }^{-1}$ (THB) & {$[\mathrm{H}=1 \times \mathrm{x}]$} & 1450 & 2223 \\
\hline Power of air compressor (W) & [I] & 900 & 1350 \\
\hline Power of light source (W) & {$[\mathrm{J}]$} & 13044 & 20000 \\
\hline Total electrical unit (units) & {$[\mathrm{K}=(\mathrm{I}+\mathrm{J}) \times \mathrm{B} \div 1000]$} & 628 & 769 \\
\hline Electrical cost, 3 THB per unit (THB) & {$[\mathrm{L}=3 \mathrm{xK}]$} & 1883 & 2306 \\
\hline Total operating cost (THB) & {$[\mathrm{M}=\mathrm{G}+\mathrm{H}+\mathrm{L}]$} & 3419 & 4662 \\
\hline Total operating cost (US\$) (36 THB per 1 US\$) & {$[\mathrm{N}]$} & 94 & 130 \\
\hline Total operating cost per gram $\left(\mathrm{THB} \mathrm{g}{ }^{-1}\right)$ & {$[\mathrm{R}=\mathrm{P} \div 1000]$} & 3.41 & 4.66 \\
\hline Total operating cost per gram ( US\$ $\mathrm{g}^{-1}$ ) & {$[\mathrm{P}=\mathrm{Q} \div 1000]$} & 0.09 & 0.13 \\
\hline
\end{tabular}

$\mathrm{ALPBR}=$ Airlift photobioreactor; $\mathrm{BC}=$ Bubble column; $\mathrm{THB}=$ Thai Baht. 
Table 4. Concentration of protein, carbohydrate and lipid of microalgae commonly used in aquaculture industry.

\begin{tabular}{|c|c|c|c|c|}
\hline \multirow{2}{*}{$\begin{array}{l}\text { Algal class } \\
\text { Species }\end{array}$} & \multicolumn{3}{|c|}{ Percentage of dry weight } & \multirow[t]{2}{*}{ Source } \\
\hline & Protein & Carbohydrate & Total fat & \\
\hline \multicolumn{5}{|l|}{ Bacillariophyceae } \\
\hline Nitzschia closterium & 26 & 9.8 & 13 & [15] \\
\hline Chaetoceros calcitrans & 31.3 & 16.4 & 22.9 & [16] \\
\hline $\begin{array}{l}\text { Chaetoceros gracilis } \\
\text { (Chaetoceros muelleri) }\end{array}$ & 48.2 & 18.9 & 28.9 & [17] \\
\hline Skeletonema costatum & 25 & 4.6 & 10 & [15] \\
\hline Skeletonema costatum & 31 & 21.5 & 1.3 & this work \\
\hline \multicolumn{5}{|l|}{ Cyanophyceae } \\
\hline Spirulina platensis & 54.2 & - & 26.6 & [18] \\
\hline Spirulina sp. & 67.0 & 25.5 & 30.1 & [19] \\
\hline \multicolumn{5}{|l|}{ Chlorophyceae } \\
\hline Dunaliella tertiolecta & 20 & 12.2 & 15 & [15] \\
\hline Nannochloris atomus & 30 & 23.0 & 21 & [15] \\
\hline \multicolumn{5}{|l|}{ Cryptophyceae } \\
\hline Chroomonas salina & 29 & 9.1 & 12 & [15] \\
\hline
\end{tabular}

\subsection{Nutritional value of $S$. costatum obtained from this work}

$S$. costatum from the experiment with the most suitable conditions determined from previous experiments was analyzed for its nutritional constituents using the standard methods as follows:

$\begin{array}{lll}\text { Protein: } & \text { Kjeldahl technique } & {[14]} \\ \text { Lipid: } & \text { AOAC method } & {[14]}\end{array}$

Carbohydrate was taken as the remaining mass after the subtraction of protein and lipid contents. Expressed as percentage of dry weight, the range for the level of carbohydrate, protein and lipid are $21.5,31.2,1.26 \%$, respectively. Examples of gross composition of microalgae are given in Table 4 where the general ranges of protein, lipid, and carbohydrate are $12-35 \%, 7.2-23 \%$, and $4.6-23 \%$, respectively [15]. Protein is always the major organic constituent when the algae are consumed as feed, Skeletonema cultivated in this work provided a reasonable amount of protein and carbohydrate but a slightly low level of lipid when compared to $S$. costatum reported by Brown [15]. Exact reasons for this were not evaluated in this work.

\section{Conclusions}

This work reveals that the cultivation of $S$. costatum in the airlift photobioreactor was superior to that in the bubble column. The optimal culture yielded a specific growth rate of $0.046 \mathrm{~h}^{-1}$ with a maximum cell concentration of $4.6 \times 10^{6}$ cells $\mathrm{mL}^{-1}$ and a productivity of $6.5 \times 10^{4}$ cells s $\mathrm{s}^{-1}$. This was due primarily to the well defined flow pattern in the airlift photobioreactor which led to a more effective light utilization of the algae. The circulatory flow in the airlift photobioreactor also helps minimize cell precipitation, and hence, high cell growth could be obtained. The finding reported here is one of the first experiences in the culture of $S$. costatum in the airlift photobioreactor and constitutes the initial step in the potential mass production. 


\section{Acknowledgments}

Financial supports from the Graduate School, Chulalongkorn University and Thailand Research Fund are deeply appreciated.

\section{References}

[1] T. Pechmanee, "Status of marine larviculture in Thailand", J. of Hydrobiologia, vol. 358, pp. 41-43, 1997.

[2] C. T. Enright, G. F. Newkirk, J. S. Craigie, and J. D. Castell, "Growth of juvenile Ostrea edulis fed Chaetoceros gracilis schutt of varied chemical composition" J. of Experimental Marine. Biology and Ecology, vol. 96, pp. 15-26, 1986.

[3] J. C. Merchuk, A. Contreras, F. Garcia, and E. Molina. "Studies of mixing in a concentric tube airlift bioreactor with different spargers", Chemical Engineering J., vol. 53, pp. 709-719, 1998.

[4] S. Krichnavaruk, W. Loataweesup, S. Powtongsook, and P. Pavasant, "Optimal growth conditions and the cultivation of Chaetoceros calcitrans in airlift photobioreactor", Chemical Engineering $J$. , vol. 105, pp. 91-98, 2005.

[5] S. Krichnavaruk, S. Powtongsook, and P. Pavasant, "Enhanced productivity of Chaetoceros calcitrans in airlift photobioreactors", Bioresource Technology, vol. 98, pp.2123-2130, 2007.

[6] R. R. Guillard, and J. H. Ryther, "Studies of marine planktonic diatoms. I. Cyclotella nana Hustedt, and Detonula confervacea (Cleve) Gran", J. of Microbiology, vol. 8, pp. 229-239, 1962.

[7] K. A. Fanning, and M. E. Q. Pilson, "On the spectrophotometric determination of dissolved silica in natural waters", Analytical Chemistry, vol. 45, pp. 136-140, 1973.

[8] F. A. J. Armstrong, "Determination of nitrate in water by ultraviolet spectrophotometry", Analytical Chemistry, vol. 35, pp. 1292-1294, 1963.

[9] T. D. Fontaine, "Spectrophotometric determination of phosphorus", Analytical Chemistry, vol. 14, pp. 77-78, 1942.

[10] J. M. Berg, J. L Tymoczko, and L. Stryer, Biochemistry, New York: W.H. Freeman, 2002.

[11] P. J. Harrison, H. L. Conway, R. W. Holmes, and C. O. Davis, "Marine diatoms grown in chemostats under silicate or ammonium limitation: I. Cellular chemical composition and steady-state growth kinetics of Skeletonema costatum", J. of Marine biology, vol. 35, pp. 1432$1793,1976$.

[12] M. Gavrilescu and R. Z. Tudose, "Modelling of liquid circulation velocity in concentric-tube airlift reactors", Chemical Engineering J., vol. 69, pp. 85-91, 1998.

[13] H. L. Tung, C. C. Tu, Y. Y. Chang, and W. T. Wu, "Bubble characteristics and mass transfer in an airlift reactor with multiple net draft tubes," J. of Bioprocess and Biosystems Engineering, vol. 18, pp. 1615-7605, 1998.

[14] Association of Official Analytical Chemist (AOAC), Official methods of analysis of official analytical chemists international, 16th ed. Arlington: Association of Official Analytical Chemists, 1995.

[15] M. R. Brown, "The amino acid and sugar composition of 16 species of microalgae used in mariculture," J. of Aquaculture, vol. 145, pp. 79-99, 1991.

[16] P. Nakseedee, "External airlift photobioreactor for Chaetoceros calcitrans", M.Eng. thesis, Department of Chemical Engineering, Faculty of Engineering, Chulalongkorn University, Bangkok, Thailand, 2008.

[17] P. Coutteau, "Manual on the production and use of live food for aquaculture," J. of Micro Algae, vol. 361, pp. 7-48, 1996.

[18] Z. Y. Li, S. Y. Guo and L. Li, "Bioeffect of selenite on the growth of Spirulina platensis and its biotransformation," J. of Bioresource Technology, vol. 89, pp. 171-176, 2003.

[19] E. Hernández and E. J. Olguín, "Biosorption of heavy metals influenced by the chemical composition of Spirulina sp. (Arthrospira) biomass", J. of Environmental Technology, vol. 23, pp. 1369-1377, 2002. 